\title{
Determinants of Destination Management System (DMS) and Tourism Industry Assessment of Madagascar
}

\author{
Dare Aurelien, Jing Zhao \\ School of Economics and Management, China University of Geosciences, Wuhan, China \\ Email: dareaurelien@gmail.com
}

Received 25 October 2014; revised 20 November 2014; accepted 18 December 2014

Copyright (c) 2014 by author and Scientific Research Publishing Inc.

This work is licensed under the Creative Commons Attribution International License (CC BY). http://creativecommons.org/licenses/by/4.0/

(c) (i) Open Access

\begin{abstract}
Tourism is one of the largest industries in the world. It is particularly significant in island economies, but also benefits significantly a range of developing and developed countries across the world. The sector is compound largely because of the interdependency between the universal production, largely managed in the established world, and the purposes around the world for which it assembles visitors. Information and communication technologies (ICTs) and tourism are two of the most dynamic drives of our worldwide economy. In the Madagascar, the tourism sector is the third largest provider of currency. Madagascar has a remarkable array of biodiversity, natural beauty and cultural resources to support tourism. Unexpectedly, of the 200,000 visitors the island per year, only about 60,000 come expressly for tourism, the rest traveling for other reasons but which could include some tourism activity. Madagascar has the potential to welcome many more tourists if the sector's growth is well planned in abroad, multi-sectorial way focusing on economic aspects, infrastructure and environmental and social concerns, particularly for community participation. This report sets out a program for equitable development of the sector and evaluates the opportunities for growth and the barriers that currently block progress and some suggestions that how to cover this era to maintain its stander of tourism sector along with. This paper describes the tourism of Madagascar, some lack of management, condition of the present tourism sector and at the end there is a conclusion of this study and recommendations on the base of present study.
\end{abstract}

\section{Keywords}

Tourism, Madagascar, Economics, DMS 


\section{Introduction}

Information and communication technologies (ICTs) and tourism are two of the most dynamic drives of our worldwide economy. As many authors have claimed, tourism must be treated as an information-intensive industry [1] [2]. Travel and tourism can be defined as an information business; because information is one of the most important factors which support actions in the tourism field such as the service industry. The technical revolution has facilitated the commercialization of tourism produces [3]. The World Tourism Organization (WTO) is trying to identify the ICT as having a role to play in tourism in 2007. E-tourism is definite as the act of choosing, organizing and booking holidays from the Internet. According to the investigations of an e-Marketer expert firm, e-tourism has become the most byproduct on the internet during the year, with turnovers exceeding 1000 billion.

\section{Madagascar}

Madagascar, officially the Republic of Madagascar and previously known as the Malagasy Republic, is an island country in the Indian Ocean, off the coast of Southeast Africa. The nation comprises the island of Madagascar (the fourth-largest island in the world), as well as numerous smaller peripheral islands. Madagascar is a biodiversity hotspot; over 90 percent of its wildlife is found nowhere else on Earth. The island's dissimilar ecosystems and exclusive wildlife are exposed by the violation of the rapidly growing human population and other environmental threats. In 2012, the population of Madagascar was estimated at just over 22 million, 90 percent of whom live on less than two dollars per day. Malagasy and French are both official languages of the state. The majority of the population adheres to traditional beliefs, Christianity, or an amalgamation of both (Figure 1).

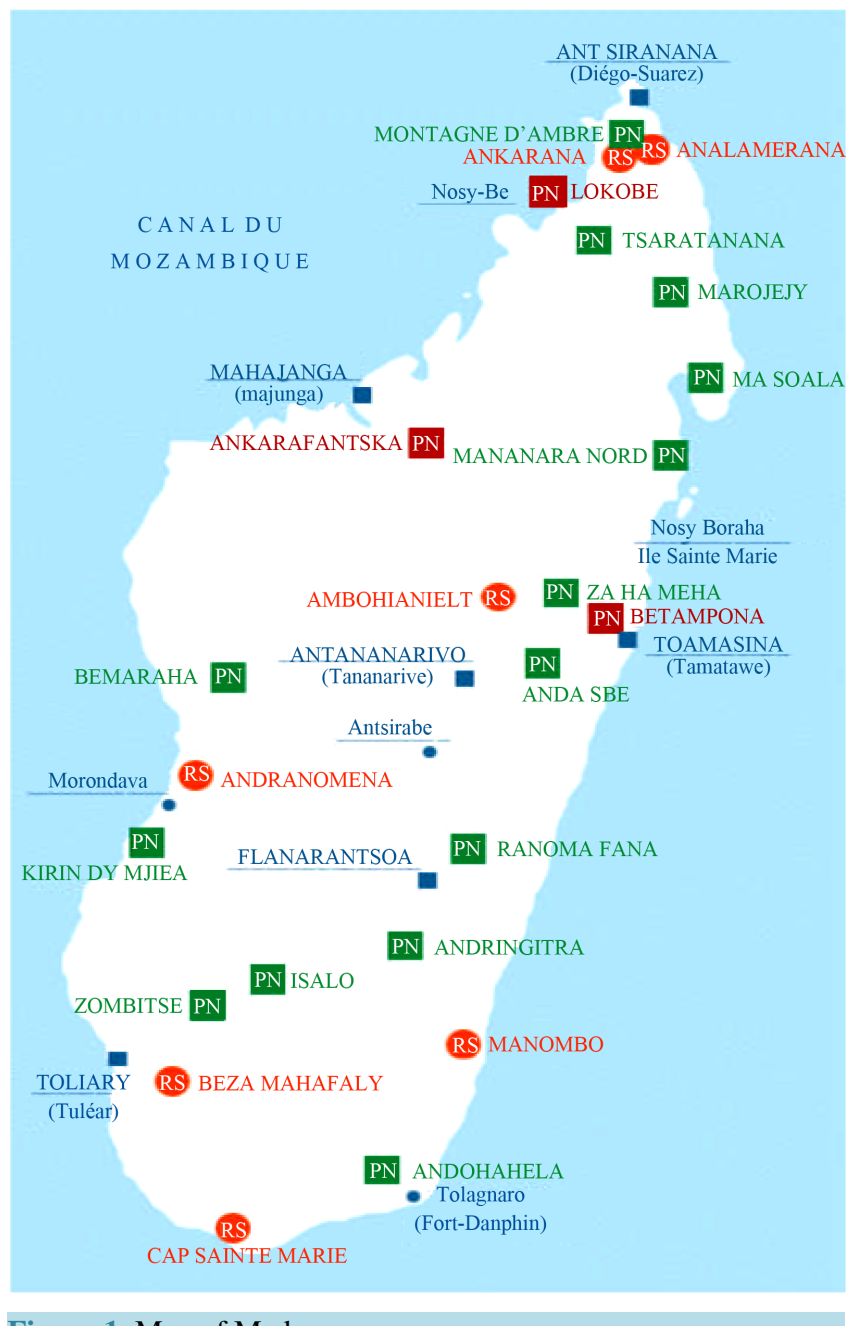

Figure 1. Map of Madagascar. 


\section{Tourism Industry Madagascar}

For Madagascar, the tourism sector is the third largest provider of currency. The total revenue is estimated to 366651047.85 USD in 2013 (Ministry of Tourism of Madagascar, 2013) against 261353189.21 USD in 2012. In 2013, the number of international tourists is totaled to 196,375 with an annual increase of $20 \%$. The tourism industry is composed of 1500 establishments employing more than 50,000 people (Malagasy Institute of Statistics, 2012). The island dominates the niche market of ecotourism with a natural capital 90\% endemic [4]. The prospective is enormous but the country is still under exploited. The Government is currently developing the tourism sector as a priority. Tourism development necessarily goes through massive use of ICT. The use of the internet sector is growing over the past decades. Today almost $50 \%$ of players in tourism have a website, and at the same time $70 \%$ of the Malagasy territory is covered by digital networks. In 2003, the number of Internet subscribers was approximately 60,000 (300\% growth compared to 2001) with 49,800 Internet users in the capital Antananarivo and the rest is located in the other five provinces [5]. 80\% of Internet users are private traders and the $35 \%$ are involved in activities directly related in tourism. Travel representatives only rely on information; virtual dealings are still in its start; only 35\% of communications in tourism come from the internet. Actors, especially the private operators (travel agencies, hotels, tour operators, tourist facilities, etc.) are conscious that the addition and use of ICT in the tourism industry is a precondition for its growth as the development of the access to the country as well as the tourism organization [6].

\subsection{Tourism as a Development Tool}

Tourism can be a effective development tool, creating economic development, expanding the economy, contributing to poverty improvement and also creating backward and forward relations to other manufacture and service sectors. In Madagascar, where rural deficiency is extensive and where the poor put pressure on the natural resource base, tourism could produce positive externalities. First, because the resources cover throughout the island, tourism generates pockets of economic growth in areas that have no substitute sources of income and occupation. In remote regions, mostly, tourism helps to ease poverty by expanding income sources. Second, tourism, properly accomplished, can help to preserve the environment, whether for ecotourism or for resort-based tourism. Madagascar's natural resources of flora and fauna and its coastal zone are among its most important but fragile economic assets. The assessment of Madagascar's assets for tourism undertaken for this report suggests that the current small size of the sector reflects substantial unrealized potential. In the past, tourism has been considered at worst as a residual to conservation, or at best a way of partially funding conservation. But tourism is complex and requires its own analysis, mainly as it is one of the major in the world and rapidly joining into a few large players. More needs to be done to build an active partnership between business and preservation, in credit of the fact that a sound business plan for tourism, an actual environmental plan, and a framework for social presence are equally strengthening and that absenteeism of one may put the others in risk.

\subsection{Virtual Benefit}

Madagascar's extraordinary natural assets, land-based and marine, make it a target destination for a diverse range of tourists. As one of the world's few mega-biodiversity countries, 95\% of its animal and plant species are endemic. Among these are 32 species of lemurs, which are the main attraction for many tourists. As the world's fourth largest island, with nearly $5000 \mathrm{~km}$ of coastline and a continental shelf that is equal to $20 \%$ of its land area, Madagascar has world-class resort assets. These are enhanced by its marine and coastal biological diversity, which is greater than in any other Western Indian Ocean country, and, in particular, by its spectacular marine mega-fauna.

1) Because most tourism to Madagascar is natural resource based, the terms ecotourism, nature tourism and tourism are used interchangeably. Although a distinction is made between ecotourism and resort tourism, the latter is also primarily based on marine natural resources and its wildlife.

2) The variety of the country's assets is reflected in its World Heritage Site: Stingy Bemaraha Strict Nature Reserve in the west, which consists of a spectacular karst geological formation. The 16 National Parks, as well as other protected areas, cover 3\% of Madagascar's land surface and are distributed throughout the island. Four marine parks are clustered around Mananara Nord, a Biosphere Reserve, on the northeast coast. Private reserves also dot the island and are visited by tourists. Because of its high endemism, Madagascar's ecotourism assets are 
unique and place it among the prime ecotourism destinations in the world. Its sun, sea and sand assets are outstanding but compete with the other better-known and better-developed resort destinations in the Indian Ocean. Madagascar also has potential as a cruise ship destination.

\subsection{The Advantage Base}

Madagascar's natural resources and, therefore, its asset base for tourism are much studied and have received considerable international financing and technical assistance for their conservation. Data about the tourism sector proper, on the demand side particularly, are, however, poor. Information is unreliable about numbers of bonafide tourists as opposed to foreign visitors, their expenditures, average length of stay, distribution around the country, and their socio-economic characteristics. This information is essential to: Know the current size of the sector and calculate benefits from tourism. Understand well what type of accommodation should be built where and which related services and products are essential Target promotion and marketing to existing and potential segments of demand and countries of tourist origin.

\subsection{Tourism and the Surroundings}

Tourism, carefully managed, is a tool for environmental protection and for financing conservation. Many "willingness to pay" studies indicate that tourists can be tapped to support environmental or cultural protection either through entrance fees, departure or other taxes, and voluntary contributions. To enhance the island's image, as well as help preserve the natural resource base, the larger accommodation units and, particularly those in sensitive ecological areas, should begin to aim for hotel accreditation that signifies that the unit has met clear environmental standards and is also a valuable marketing tool.

While economic cost benefit analysis may capture all streams of revenues and costs, where assets are public goods no quantification may be available. Yet tourism assets are scarce and generate "rents" and much dissention between countries and developers can be traced to how best distribute these rents between the travel industry, tourists and the host country. Clearly, a charge for use of these assets is desirable if the asset is to be used sustainably. Many direct and indirect tools are available but it is important that tourism operators as well as government policy makers and environmental officials take heed of this important issue. Measures for ensuring that resources collected are managed responsibly include arrangements with NGOs and other providers.

\subsection{Sector Management}

The Ministry of Tourism has capable people in its leadership echelons, but a low budget that renders it ineffective. The Ministry has also not succeeded in convincing other branches of government of tourism's significance and contribution to the economy, i.e., in classifying tourism as an export industry or attracting additional resources for infrastructure and promotion. The Association National pour la Gestation des Aires Protégées (ANGAP) has been an effective enough manager of the national parks and reserves, has built a solid reputation and works effectively with NGOs but faces funding shortfalls in the short run. Given the critical role of the national parks and reserves for conservation and for tourism, ANGAP urgently requires resources to enable it to continue its operations. GEF is working with ANGAP to create a trust fund and to increase its revenue generation from park fees.

\subsection{Future Development}

Tourism to Madagascar has recently been affected by acts of terrorism worldwide (September 11, Moscow, Bali and Nairobi) and by political upheavals at home. The WTO suggests that tourism is resilient and will bounce back-and indeed some countries in Asia saw growth in tourism in 2002. Mauritius for example, has been very successful in 2002 selling itself as a "safe haven" and its tourism grew. Indeed, in spite of the political hiatus in Madagascar in 2002, occupancies in higher income hotels seem to have held up; smaller operations have seen a decline. The emerging pattern in major markets is one of taking more frequent, shorter vacations, with longhaul destinations suffering by comparison with short haul trips (WTO). It is time for caution in extrapolating past trends but in the absence of crises, tourism can increase its Contribution to the economy. In the absence of targeted interventions for the sector, tourism can accommodate some

Expansion in current numbers until capacity constraints kick in. Capacity is defined, principally, as the avail- 
ability of quality accommodation and services and, where relevant, seats on internal and international flights. Without a more detailed survey of the many destinations visited by tourists, the exact timing of when such constraints will restrict tourist numbers cannot be forecast. It is a remarkable tribute to Madagascar's assets and its people, that despite lack of competitiveness in many facets of the sector, most tourists express high satisfaction with their visit. The number of return tourists also confirms the level of satisfaction. Madagascar has sufficient and varied assets that can be brought on stream successively over time to cater to different segments and niche markets, as well as income groups, of the tourism market. The resort market is the most competitive segment of demand worldwide and Madagascar competes with destinations in the Caribbean, South Pacific, and other "island paradises", as well as with the rest of the Indian Ocean. A challenge for Madagascar is to maintain its preeminent position as an ecotourism and adventure destination and simultaneously build up its image for other segments of demand, such as the resort market. It should also explore options for creating regional tours as suggested above with other islands in the Indian Ocean and neighboring countries on the continent.

\subsection{A Future Approach for Tourism}

Tourism may be an efficient development tool for Madagascar because it can be a Catalyst for economic growth, much of it in rural areas, and can create a number of positive externalities to alleviate poverty and protect the environment. As several other countries have done, Madagascar intends to complete master plans 4 for its tourism zones (some are already underway) and, with the support of GATO AG (a German apex organization for tourism), develop a "concept for tourism" in order to provide short- and long-term frameworks for tourism development. These studies should examine tourism's potential externalities and integrate tourism within the macro-economic framework to create linkages to other productive sectors.

The study should also identify poles for development, ways to eliminate constraints and barriers to growth, encourage sustainability through physical planning and community participation, as well as on an analysis of demand and proposals for appropriate tourist accommodation and services. Local communities are to be included in a participatory process at an early stage and the study should also address the policy framework, financing of tourism, the "greening" of the island, pro-poor tourism, and creating clusters of high-quality accommodation and services to upgrade the product. The study is to be completed by the end of 2003 .

\section{Tourism and Economy of Madagascar}

Tourism is one of the largest industries in the world. It is particularly significant in island Economies, but also benefits significantly a range of developing and developed countries across the world. The sector is compound largely because of the interdependency between the universal production, largely managed in the established world, and the purposes around the world for which it assembles visitors. An urbane supply chain and rapid alliance in the nineties, in airlines, hotel chains and tour operators/travel agents describe the industry, which makes concentrated use of information organization in its operations and of information expertise in questions and marketing. Within an individual country, tourism is also complex because of its cross-sectorial relations and the connections that are obligatory for its sustainability between the domestic and foreign private sector and several branches of central and local government, as well as with local communities visited by tourists. The sector has the possible to attract asset in a range of housings and services, to generate investments in substructure that also advantage other sectors and communities, and to stimulate demand in other sectors. In spite of a high possible for tourism, tourism in Madagascar is underdeveloped

\section{Economic Impact of Tourism}

Tourism produces considerable economic movement in other production and service sectors. The structure sector is clearly impacted during structure of hotel and tourism-related facilities, including substructure. Hotel and other types of accommodation produce economic activity through regressive and onward relations to agriculture and fishing and developed. Tourist services and tourists themselves, through individual expenditure in and outside the tourist accommodation, create a call for transport, banking, insurance, telecommunications, medical, security and retail services, and, particularly, handcrafts and other souvenirs. Tourism clues to the formation of businesses connected to water, mountain and exploration sports and other recreation activities, as well as every facet of travel and transport. Personal services related to spa treatments and traditional beauty services are also 
expanded by the presence of tourists. In 1993, the United Nations called on all countries to develop a National Satellite. Account for Travel and Tourism (TSA) to provide a reliable measure of its true influence to the national economy.

The Dominican Republic, with assistance from WTO and UNDP, undertook an experimental TSA in 1993, updated in 1998, designed to be a model for small island nations. The data for 1996 indicate that tourism expenditure as a percentage of GDP amounted to 20.5\%. The comment of the Director of National Accounts of the 36 tourism to GDP and to export revenues is considerably higher in TSA than in conventional calculations that use only estimated direct tourist expenditures. Traditionally, tourism is included in sectorial GDP in Madagascar as "Trade, Hotels and Restaurants". By lumping trade with tourism, the contribution of neither can be well understood. In Madagascar, ecotourism or adventure tourism is the largest segment and some argue for foregoing the "resort market" (beach or mountain based). This requires closer analysis; for many countries find that their product line is made up of a variety of segments. It does not mean that Madagascar should forego the resort market in favor of ecotourism quite the contrary, Madagascar needs an internationally recognized brand name hotel or two to put it on the tourism map. In many successful tourism countries the tourism product mix is quite varied in Senegal where the Government argues only for "high end" tourists, in fact there are many backpackers, assumed to be low spenders; similarly, Mauritius, although known for its superlative five star hotels, is seeing a rapid growth of (often unregulated) villa and self-catering accommodation. There needs to be careful analysis of the Product mix within Madagascar and attention should also be given to creating regional circuits in the Indian Ocean community

\subsection{Employment}

Tourism generated some 17,564 jobs in hotels and restaurants, of which 3554 in travel and entertainment establishments in 2001 which increased with the passage of time, as shown in Table 1.

\subsection{Taxes}

Government revenues are produced through numerous taxes, including sales; value added (VAT), room, airport or departure, corporate income, payroll, social security, and property taxes. Revenues are also resulting from import duties and from aircraft arrival fees and voyage and boat docking fees. The particular amount of taxes elevated from tourism is difficult to approximation because of the dispersal of tourism expenses and the variety of goods and services used by tourism. In Madagascar, tourism generated tax revenues estimated at MF 62.5 billion in 1999 including VAT and income taxes. Whether these are income taxes on hotel and restaurant employees only or also include tour operators, transport services related to tourism, etc., needs to be clarified with the Government.

\section{Analytical Approach}

The information base to assume the type of economic analysis that would deliver a better understanding of tourism's involvement to the economy is not in place in Madagascar. Policy preparation for the sector needs to be based on a better understanding of the costs and benefits of different types of tourism development. The Government would need backing with this enterprise. Whether Madagascar develops a major tourism destination will be contingent on the quality of sector management. Tourism is fundamentally a private sector movement but is highly reliant on public sector sustenance. Tourism cuts transversely many sectors and there is frequently little communications between them. Famous among the ministries whose actions are related to tourism, in addition to the Ministry of Tourism, are, for example, the Ministries of Finance, Land, Culture, Public Works,

Table 1. Tourism employment.

\begin{tabular}{ccccccc}
\hline & $\mathbf{1 9 9 6}$ & $\mathbf{1 9 9 7}$ & $\mathbf{1 9 9 8}$ & $\mathbf{1 9 9 9}$ & $\mathbf{2 0 0 0}$ & $\mathbf{2 0 0 1}$ \\
\hline Hotels \& Restaurants & 11,103 & 11,318 & 11,655 & 12,640 & 13,628 & 3231 \\
Travel \& Entertainment & 2604 & 2661 & 2708 & 2934 & 3554 \\
Total & 13,707 & 13,979 & 14,363 & 15,574 & 16,859 \\
\hline
\end{tabular}

Source: Ministry of Tourism. 
Agriculture, Labor and Commerce. To be successful, tourism requires coordination and complementarity between the Government and the private sector, civil society in general and, in particular, with local communities that are specifically impacted by tourism, where NGOs can enable the process. Only an ongoing dialogue between the public and private sectors can lead to effective tourism management. Despite some development, that dialogue is not yet in place. A strengthening of public and private sector institutions, joint with a strengthening of organization mechanisms among them, should facilitate the process but specific measures should be put in place as soon as possible to validate the discourse.

Destination Management is the only tool to make the betterment in tourism sector, Destination Management Organization will be a leading and most significant body to manage a destination developing into a "total destination management system". The DMS will become the final source of strategic aptitude and grow as a communication center for a destination. The DMSs community will be required after by Government organizations and large establishments for information and leadership [7]. DMS should not only help to hand pre-trip, post arrival information requests, but also assimilate an availability and booking service too [8] [9]. DMS could increase visitor traffic, attract the right market segment with the provision of an accurate and up to date comprehensive electronic database [10]. Madagascar has an inspiring array of biodiversity, natural beauty and cultural resources to provision tourism. The nation includes the island of Madagascar, as well as many smaller marginal islands. For Madagascar, the tourism sector is the third largest earner of currency. The potential is huge but the country is still under exploited. The Government is currently developing the tourism sector as an importance. Due to the fact that tourism has been familiar as one of the key sector to drive economic development and that the usual typical has not carried about sensitive socio-economic growth, a number of attitudes have been scheduled to improve tourism economic associations.

In Table 2 and Figure 2 we can see the number of people arrive in Madagascar from the world to see the beauty and attractions of Madagascar. In table we can see history of people from 1995-2012. In these years we scan see ups and down of people which were travelling to Madagascar. In should increase but in some years its decrease the reason may the lack of government management in this sector or unavailability of DMS within the country, one reason may be the high rate of air fare, so Government should look into these issues to make the tourism sector more efficient, which can increase the economy of the country.

\section{Conclusions and Suggestions}

As we can say Madagascar is a paradise on earth due to its beauty and abundant attractive scenery. The Government has a big portion of GDP which gets from this sector, but as per my conclusion, it can increase more if we try to develop the strong DMS in the country along with strong ICT system. The research shows that DMO within Madagascar does appreciate the importance of understanding DMS and those they can deliver the destination with diffident benefit and long-term benefits. An important number of DMS are not delegating DMS regardless of the advantages can be expanded. The DMS still prefers to purchase the system and few advances to build their own DMS, lack of subsidy and scientific proficiency are seen as two of the major problems.

\section{Table 2. International tourism, number of arrival in Madagascar.}

\begin{tabular}{cccccc}
\hline Sr. No & Year & No. of people & Sr. No & Year & No. of people \\
\hline 1 & 1995 & 75,000 & 10 & 2004 & 229,000 \\
2 & 1996 & 83,000 & 11 & 2005 & 277,000 \\
3 & 1997 & 101,000 & 12 & 2006 & 312,000 \\
4 & 1998 & 121,000 & 13 & 2007 & 344,000 \\
5 & 1999 & 138,000 & 14 & 2008 & 375,000 \\
6 & 2000 & 160,000 & 15 & 2009 & 163,000 \\
7 & 2001 & 170,000 & 16 & 2010 & 196,000 \\
9 & 2002 & 62,000 & 17 & 2011 & 225,000 \\
\hline
\end{tabular}

Source: http://data.worldbank.org/indicator/ST.INT.ARVL. 


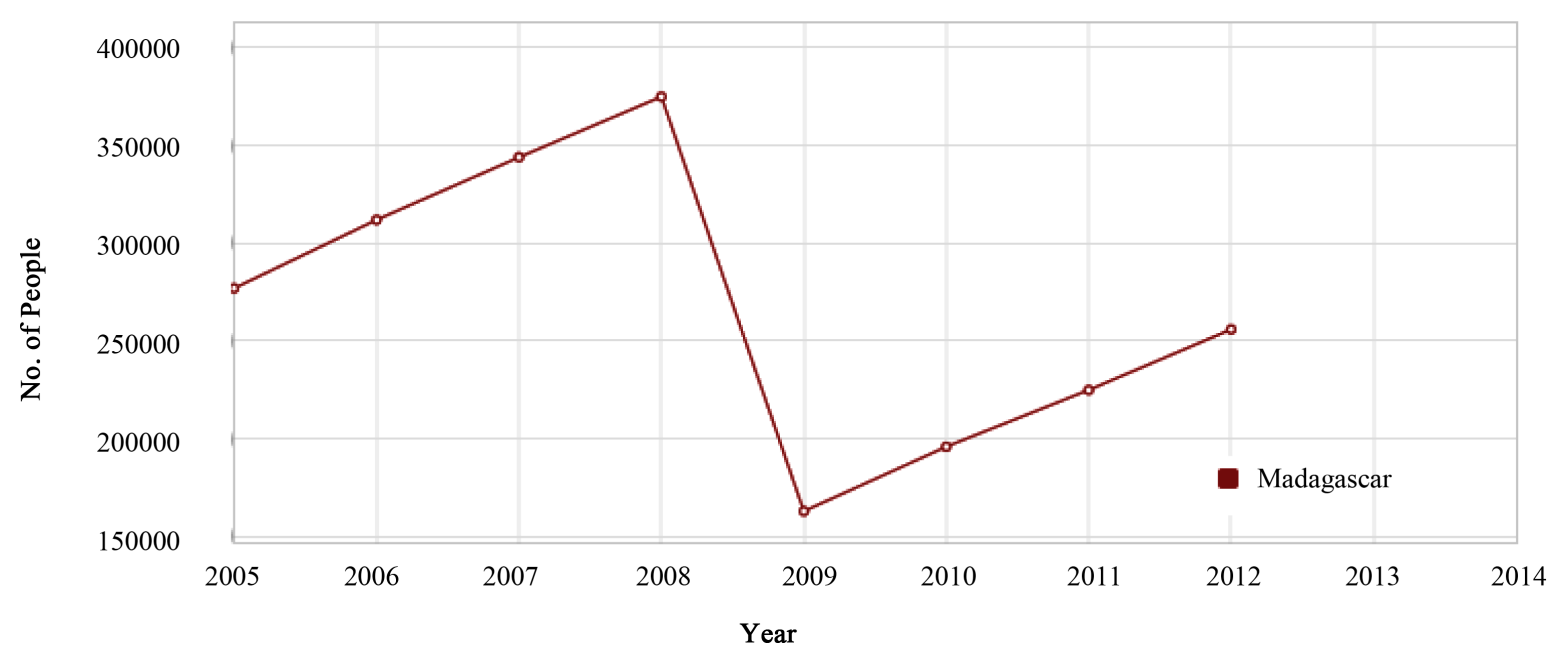

Figure 2. Graph number of people arrival in Madagascar.

The World Bank's existing program in Madagascar is assisting to remove constraints to development. With greater planned focus, it could raise the outreach of tourism to rural areas and help relieve poverty. Because tourism is cross-sectoral nearly any donor-assisted-assisted activity could have an important impression on tourism, as, for example, all organization projects, including water, power, telecommunications, as well as health and education, if a focus on tourism is involved as part of the significant sector approach. The national transport plan will help to improve those roads, secondary airports and, possibly, railways, ports and river navigation that would directly benefit the growth and/or expansion of tourism. The rural roads project could be involved in opening up isolated areas with tourism possible. New projects in Madagascar should consider the impacts on and potential benefits to tourism. Policy discussions with the Government should comprise the need to progress the business environment for tourism and, particularly, to adopt measures that will enable new investors to follow-through on their asset plans. An agricultural sector evaluation should reflect tourist plea. Public expenditure reviews should analyze the taxes derived from tourism and government expenditures for the tourism sector, including for elevation and training, which should be funded through a partnership with the private sector. Poverty missions should review the potential of tourism to produce income in specific rural areas and environmental assignments should assessment the potential of tourism for rising revenues to preserve natural resources used for tourism.

DMS can help the traveler, but also growth the economy of any country, a country like Madagascar, which is a under developing country, not only need to create these types of system itself, but the Government should also inspire DMS system in the country for the foreigner investors. The vendors of DMO are also responsible to create a confirmatory environment for the tourists, develop the market request and driven tourism packages, enlarge the service quality and product growth of local contractors and improve the environmental performance of private businesses. To support maintainable tourism development, promote responsible travel and give motivations to travelers to understand and protect the local culture and environment they are staying. Government of Madagascar should take some serious and suitable steps for the betterment of this sector because SWOT analyses that the weakness and threats of this sector are high. Apart from it, a large number of Madagascar people attach with this occupation, so by the betterment of this sector, the Government can promote the economy of the country as well as the life of people. A sustainable and developed DMS are in need of time for this sector within country.

1) Tourism is highly modest in some markets, mainly the international beach resort market; In any event, the country will need to launch a product line that offers assorted involvements. There is also the chance to create regional markets with nearby islands and countries on the African landmass and thus produce a produce line with very high value additional for the country.

2) The Government identifies the need to advance the statistical base for tourism but is unnatural by lack of funding. These costs may persuade the Government to find the resources to assist with this important task of improving the tourism database.

3) Policy design for the sector needs to be based on a better considerate of the costs and benefits of diverse 
types of tourism and policies should include an considerate of how to stimulate the regressive and forward relations to other creation and service sectors. A study of the linkages between tourism and agriculture would help understand the demand from the tourism sector for agricultural produce; a study of handicrafts would help strengthen linkages between tourism and that sector and promote higher value added from tourism.

4) Air travel to Madagascar is ultra-expensive, inflexible, and limits the number of tourists who can afford to travel as well as the main source markets from which tourists come. Part of this is due to the distances but part is also due to high fares. An expansion of demand from European countries other than France and from other supplier markets will require better air access, cheaper fares and direct marketing. Moreover, the international airport in Antananarivo needs upgrading to permit the landing of larger planes and for greater passenger comfort. It would be interesting to review existing bilateral agreements 70 in Africa and to open several airports in Madagascar to international flights and thus diversify the supply of air services.

5) The Government should focus on reform measures to reduce transactions costs for investors and machinists.

6) The lack of training and talents is a major weakness in all activities and all sectors, including the handicrafts sector. To enlarge Madagascar's tourist markets, a significant effort must be made to teach languages in schools and to local people who have regular interaction with tourists.

\section{References}

[1] Poon, A. (1993) Tourism, Technology and Competitive Strategies. CAB International, New York.

[2] Sheldon, P. (1997) Tourism Information Technology. CAB International, New York.

[3] Sheldon, P.J. (1993) Destination Information Systems. Annals of Tourism Research, 20, 633-649. http://dx.doi.org/10.1016/0160-7383(93)90088-K

[4] Crompton, D.E. (1999) An Action Plan for Sustainable Tourism Development in Panama. Tourism Development and Marketing Plan for Panama. Nathan Associates, Government of Panama. IADB.

[5] http://www.omert.org/plan-du-site/

[6] Crompton, D.E. (1996) Annexes III (Coastal Zone Management) and VI (Tourism) “Belize Environmental Report” No. 15543-BEL. World Bank. Latin America and the Caribbean Region ODA.

[7] Varghese, B. (2013) Intervention of Destination Management Organization's in Tourist Destinations for Branding, Image Building and Competitiveness-A Conducive Model for Karnataka. International Journal of Investment and Management, 2, 50-56. http://dx.doi.org/10.11648/j.jim.20130203.13

[8] Buhalis, D. (1997) Information Technology as a Strategic Tool for Economic, Social, Cultural and Environmental Benefits Enhancement of Tourism at Destination Regions. Progress in Tourism and Hospitality Research, 3, 71-93. http://dx.doi.org/10.1002/(SICI)1099-1603(199703)3:1<71::AID-PTH42>3.0.CO;2-T

[9] Frew, A.J. and O’Connor, P. (1998) A Comparative Examination of the Implementation of Destination Marketing System Strategies: Scotland and Ireland. In: Buhalis, D. and Schertler, W., Eds., Information and Communication Technologies in Tourism1998, Springer, Wien, New York, 258-267.

[10] Sheldon, P.J. (1993) Destination Information Systems. Annals of Tourism Research, 20, 633-649. http://dx.doi.org/10.1016/0160-7383(93)90088-K 
Scientific Research Publishing (SCIRP) is one of the largest Open Access journal publishers. It is currently publishing more than 200 open access, online, peer-reviewed journals covering a wide range of academic disciplines. SCIRP serves the worldwide academic communities and contributes to the progress and application of science with its publication.

Other selected journals from SCIRP are listed as below. Submit your manuscript to us via either submit@scirp.org or Online Submission Portal.
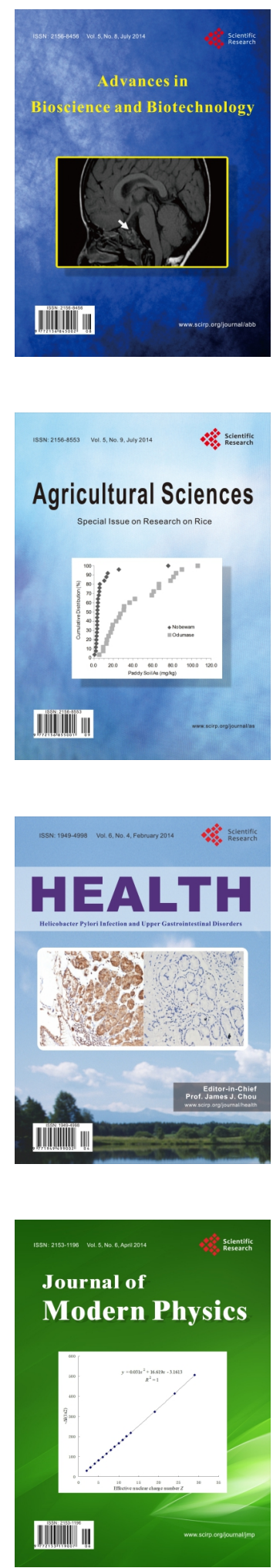
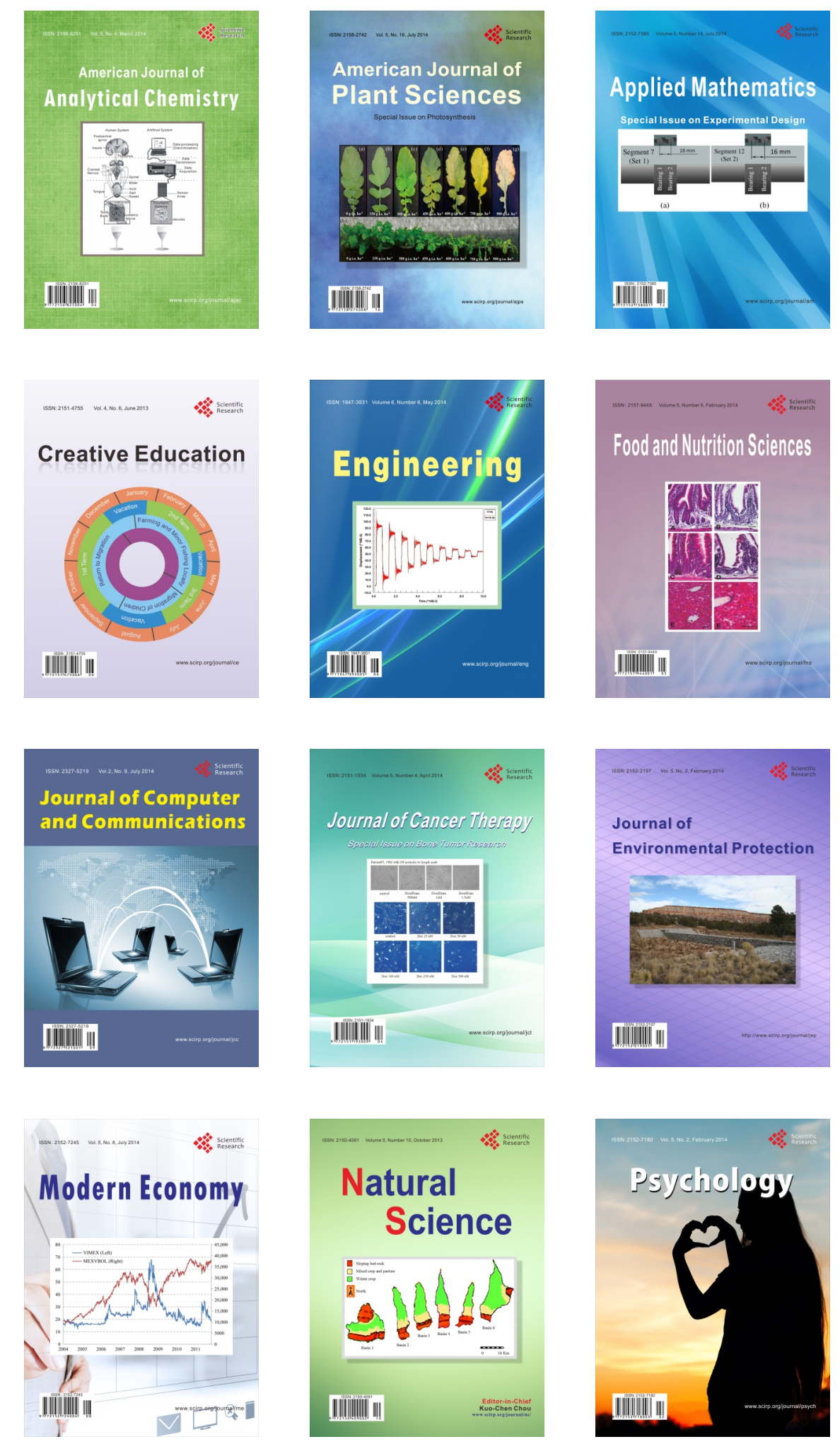